\title{
VARIATIONS IN POLLEN DEPOSITION OF SOME PLANT TAXA IN LUBLIN (POLAND) AND IN SKIEN (NORWAY)
}

\author{
Krystyna Piotrowska
}

\author{
Department of Botany, University of Life Sciences, \\ Akademicka 15, 20-950 Lublin, Poland \\ e-mail: krystyna.piotrowska@up.lublin.pl
}

Received: 8.03.2010

\begin{abstract}
This paper analyses pollen deposition in Lublin (Poland) and Skien (Norway). The studies were conducted in the years 1999 and 2000 using the gravimetric method and a Durham sampler. The study results varied both between years and cities. 10 more plant taxa were identified in Lublin than in Skien. In Lublin the highest airborne pollen concentrations were recorded in April, whereas in Skien in May and July. Betula, Pinaceae and Poaceae were the dominant taxa at the sampling site in Poland, while in Norway these were Pinaceae, Betula and Urtica. During the period of two years, annual pollen sums for most taxa were higher in the conditions of Poland, and the maximum pollen concentrations of Betula and Poaceae were higher in Poland, while for Pinaceae the pollen counts were higher in Norway.
\end{abstract}

Key words: aerobiology, pollen monitoring, gravimetric method, Lublin, Skien

\section{INTRODUCTION}

The condition for the occurrence of pollen allergy symptoms is contact with an allergenic agent. Therefore, the best method for pollinosis control is to avoid contact with allergens. When planning a holiday or other trip, it is worth to choose places of low allergenic pollen concentration. According to D' A m a to and Spieksma (1990), strongly allergenic plants such as: Corylus, Alnus, Betula and Poaceae, start to shed pollen a month later in northern Europe than in central Europe. A comparison of pollen deposition for the three abovementioned taxa in Lublin and Skien is presented in a earlier paper (P i o tr o w s k a, 2004).

The aim of the research was to determine the qualitative and quantitative composition of pollen deposition in Lublin and Skien as well as to compare airborne pollen counts in the abovementioned cities in order to establish whether there is any difference in the time when pollen is found in the atmosphere of south-eastern Norway and eastern Poland.

\section{MATERIALS AND METHODS}

The studies were carried out in the years 1999 and 2000 in Lublin (Poland) and Skien (Norway), two cities which are distant from each other by $1200 \mathrm{~km}$ in straight line. The airborne pollen concentration was determined using the gravimetric method and a modified Durham sampler (D u rham, 1964). Slides were changed weekly. The results were expressed as the number of pollen grains per $1 \mathrm{~cm}^{2}\left(\mathrm{p} / \mathrm{cm}^{2}\right)$.

In Lublin $\left(51^{\circ} 14^{\prime} \mathrm{N}, 22^{\circ} 34^{\prime} \mathrm{E}\right)$ the sampling site was located within an area of residential buildings, characterized by a relatively high building density. Trees of the following genera: Betula, Salix, Acer, Quercus, Fraxinus, Populus, were found in the vicinity of the sampling site. The Durham trap was located at a height of $9 \mathrm{~m}$.

Skien $\left(59^{\circ} 20^{\prime} \mathrm{N}, 9^{\circ} 50^{\prime} \mathrm{E}\right)$ is situated in south-eastern Norway in the district of Telemark, at a distance of about $100 \mathrm{~km}$ from Oslo. The sampling site in Skien was located at the city outskirts. In the close vicinity, there is a mixed forest with a predominance of Picea, Betula, Quercus, Corylus, Fraxinus. Urtica occurred nearby in large numbers. The Durham trap was located at a height of $3.5 \mathrm{~m}$ above ground.

Mean annual temperature in Lublin is $7.4^{\circ} \mathrm{C}$, whereas in Skien it is $5.9^{\circ} \mathrm{C}$. More precipitation is recorded annually in Skien than in Lublin, $840 \mathrm{~mm}$ and $550 \mathrm{~mm}$, respectively. 
The study results for each city are presented, among others, in the form of the phenological pollen calendar which was prepared in accordance with the IAA's recommendations (S p i e k s m a , 1991).

\section{RESULTS}

During pollen monitoring, there was demonstrated a greater diversity of airborne pollen in Lublin than in Skien. 40 taxa were identified in Lublin (Fig. 1), whereas in Skien this number was 30 (Fig. 2). Marked quantitative differences were also found. In Skien significant pollen deposition (with the annual total of more than 50 grains) was recorded with respect to 10 taxa, whereas in Lublin for 18 taxa (Table 1). In both cities, some taxa were represented sporadically and their single grains were recorded; this applied primarily to entomophilous plants (Table 1).

The highest airborne pollen concentrations in Lublin were found in April, whereas in Skien in May and July (Fig. 3). Pollen grains noted in Skien in July probably originated in their major part from longdistance transport. In Lublin the dominant taxon was Betula, followed by Pinaceae and Poaceae, while in Skien these were Pinaceae, Betula and Urtica (Tab. 1). In both years of the study in Lublin, there was found much more arboreal pollen (AP) than non-arboreal pollen (NAP). The AP percentage in the annual sums of all pollen grains was within the range of $78.1-81.2 \%$. In both years of the study in Skien, large differences were noted between AP and NAP deposition. In 1999 the percentage proportion of arboreal pollen in the pollen spectrum was $52.2 \%$, whereas in 2000 it was $85.7 \%$ (Table 1).

There were also differences in the start dates and duration of the pollen seasons. Mean air temperature had the greatest effect on the start date of the pollen season. Due to low temperatures at the beginning of 1999 , the pollen season in Skien was delayed by 5 weeks relative to Lublin. The abundant and dense occurrence of pollen grains in the atmosphere of Lublin was recorded from the last week of February, while in Skien from the 3rd week of April when temperature increased above $5^{\circ} \mathrm{C}$. Higher temperatures in 2000 promoted an earlier start of the pollen season in Skien, which took place at the same time as in Lublin (Fig. 3).

In 1999 most taxa were represented in much larger numbers in pollen deposition in Lublin than in Skien, the following being the exception: Pinaceae and Urtica. In 2000 higher annual pollen sums were recorded in Skien than in Lublin for Corylus, Alnus, Ulmus, Fraxinus, Pinaceae, Rosaceae and Urtica (Table 1). The comparison of the pollen seasons in both cities shows that the greatest differences related to tree plants. The mean start dates of the pollen season were similar, but the periods of higher airborne pollen concentration were noted at different times. The maximum Betula pollen deposition occurred in Lublin in the second week of April, while in Skien at the beginning of May (Fig. 4). The seasonal maxima for Fraxinus and Quercus were noted two weeks earlier in Lublin than in Skien. High values of Pinaceae pollen influx in both cities were recorded in the second half of May, and in Skien a second peak appeared additionally in the middle of July, outside the pollen shed period of the neighbouring plants. The start and end of the grass pollen season as well as the seasonal maxima were recorded on similar dates at both sampling sites. However, grass pollen deposition was higher in Lublin than in Skien. The maximum Rumex pollen concentrations were observed two weeks earlier in Lublin than in Skien. The Plantago pollen season in Skien was shorter and less abundant than in Lublin. In Skien much higher Urtica pollen values were found. The seasonal maxima were recorded there a month earlier than in Lublin. The mugwort pollen season pattern in both cities was very similar, and the maxima occurred at the same time. In Skien ragweed pollen was noted in smaller amounts and later than in Lublin (Fig. 4). 


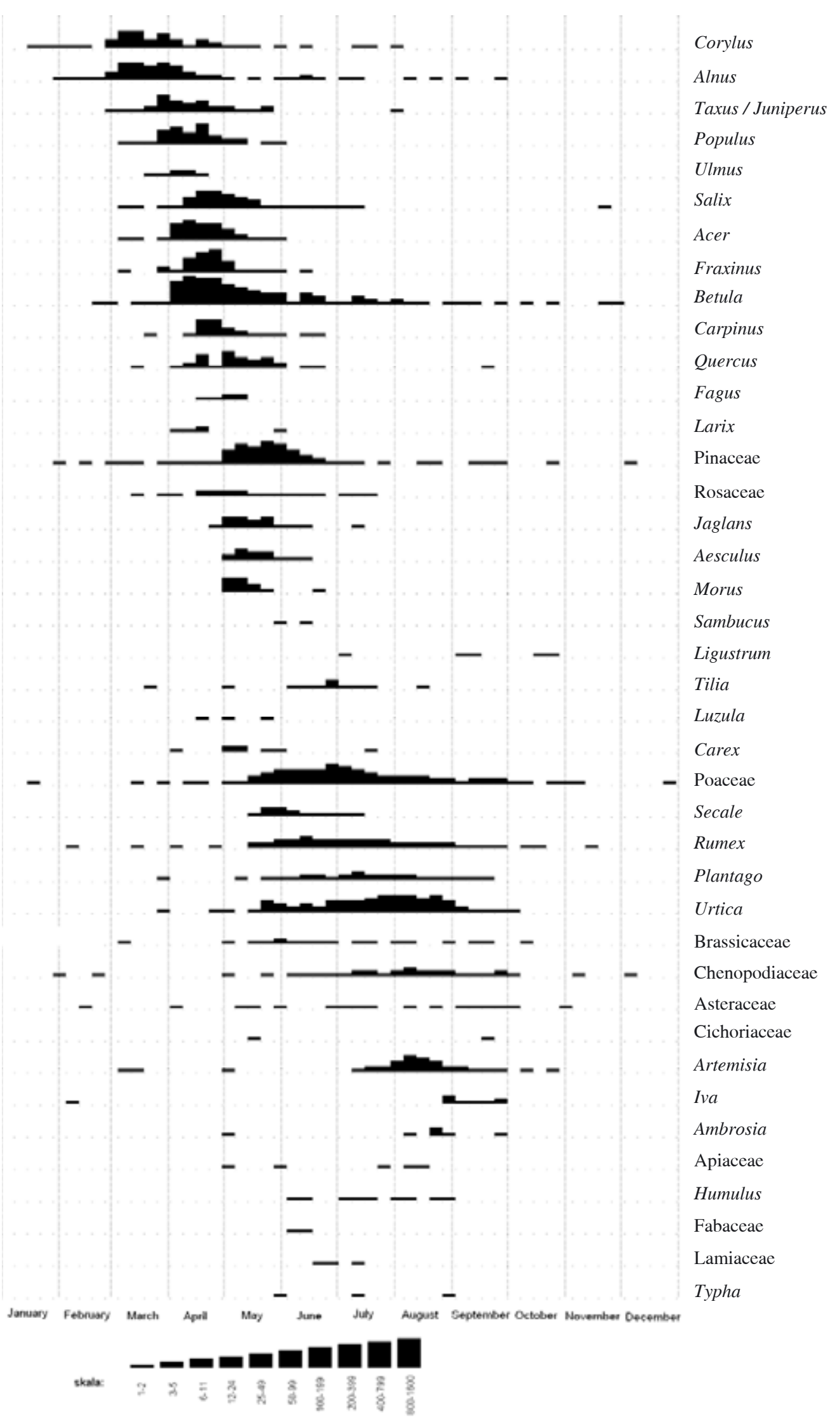

Fig. 1. Pollen calendar for Lublin, average 1999-2000 years 


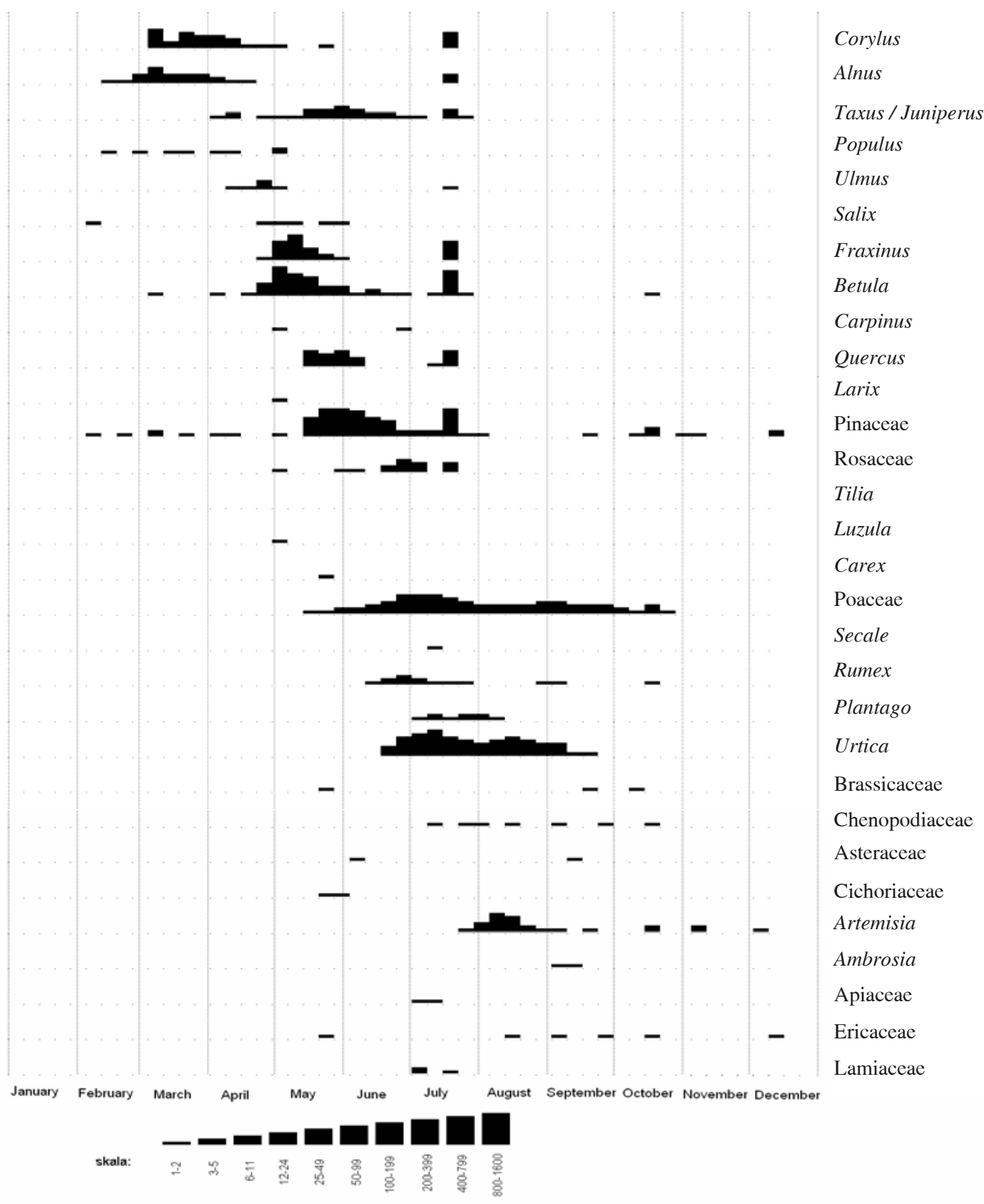

Fig. 2. Pollen calendar for Skien, average 1999-2000 years 

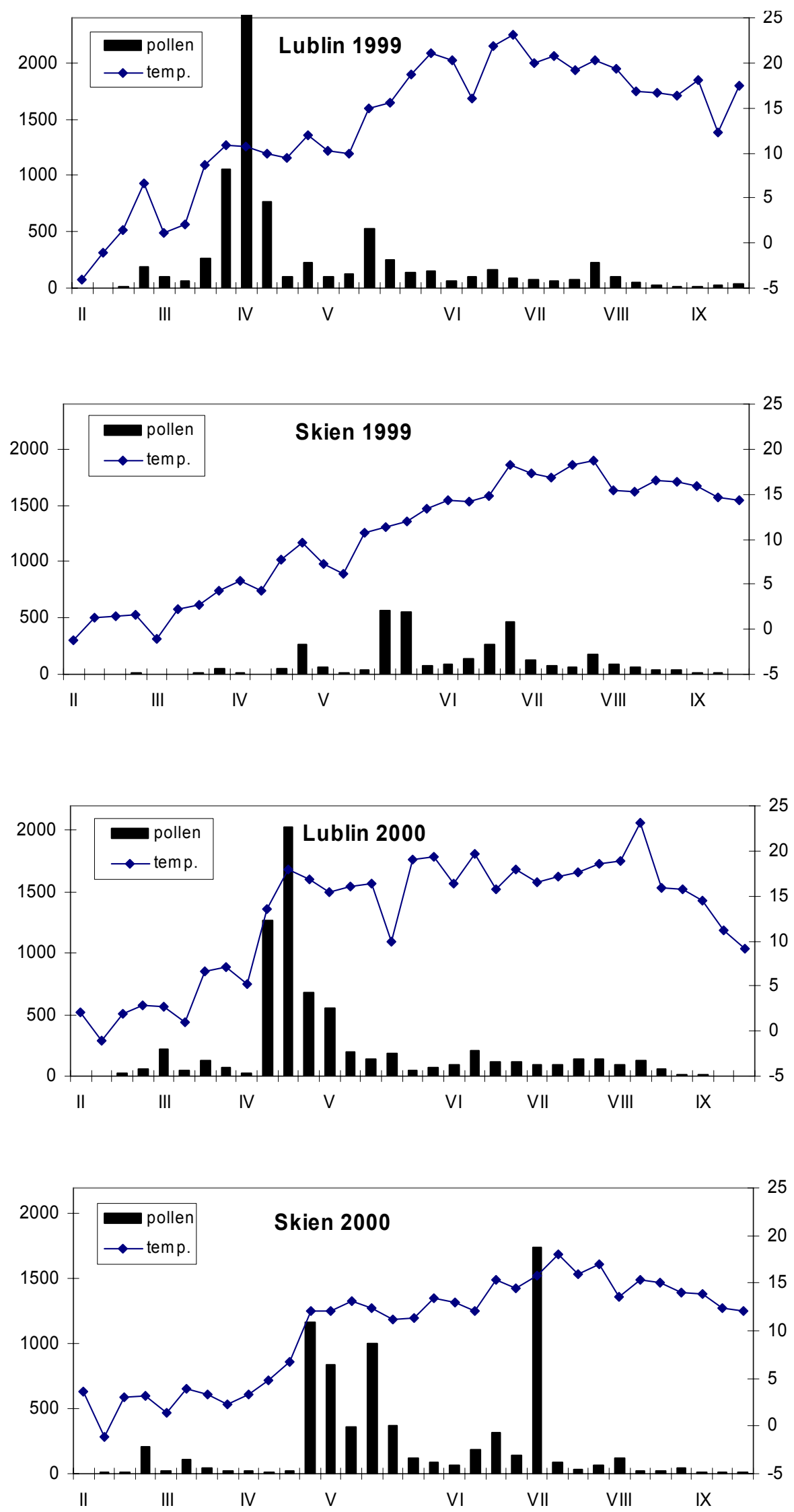

Fig. 3. Pollen deposition of all plant taxa in Lublin and Skien relative to mean air temperature 

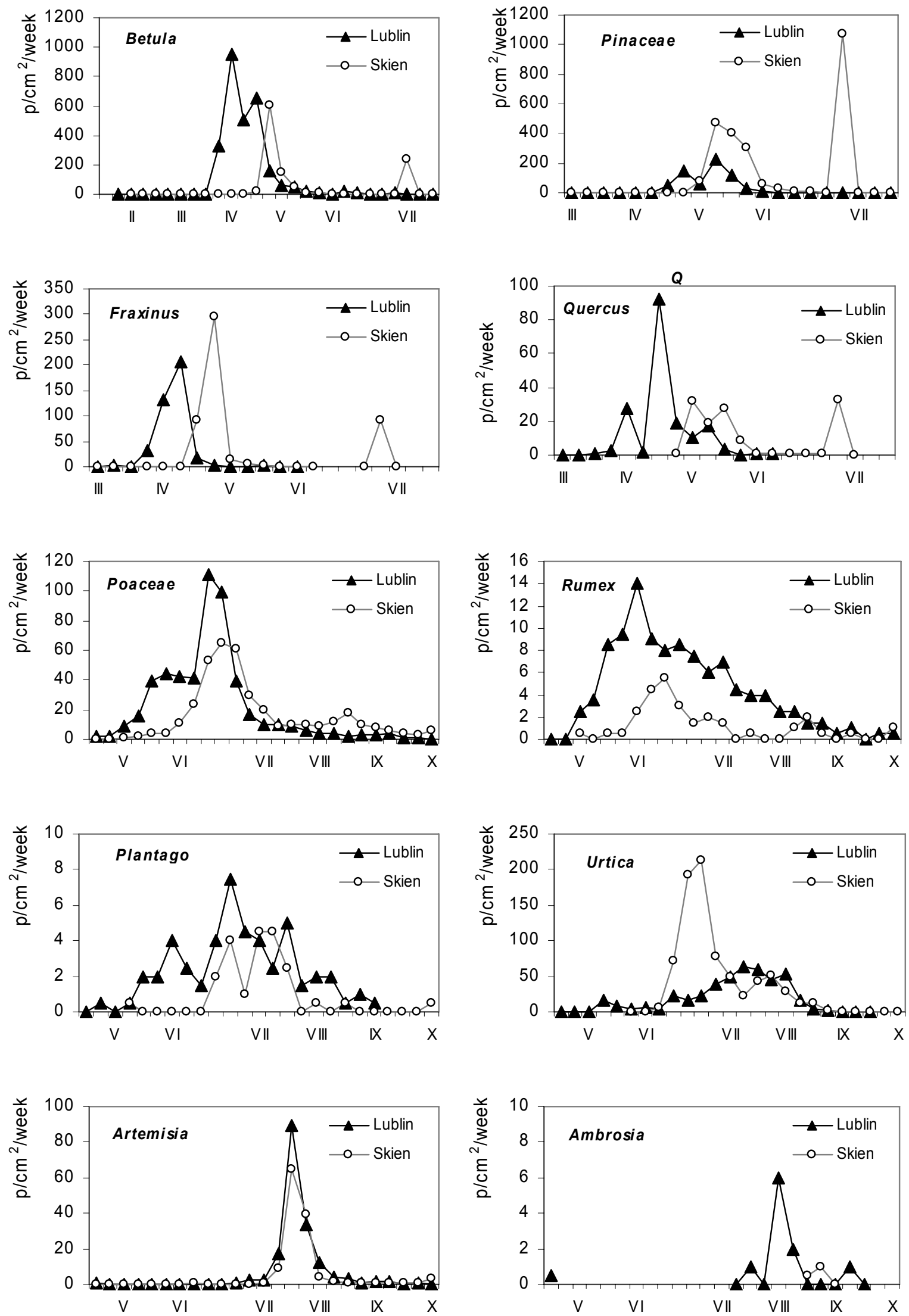

Fig. 4. Comparison of pollen concentration of selected taxa in Lublin and in Skien (average 1999-2000). Note the different scales 
Table 1.

Annual pollen sums and pollen percentages in pollen deposition in Lublin and Skien.

Lublin

\begin{tabular}{cccc}
1999 & 2000 & \\
\hline annual & $\%$ & annual & $\%$
\end{tabular}

total share total share

\begin{tabular}{|c|c|c|c|c|}
\hline & & & & \\
\hline Corylus & 193 & 2.6 & 275 & 4.1 \\
\hline Alnus & 390 & 5.2 & 148 & 2.2 \\
\hline Taxus/Juniperus & 114 & 1.5 & 159 & 2.4 \\
\hline Populus & 308 & 4.1 & 305 & 4.5 \\
\hline Ulmus & 19 & 0.3 & 3 & 0.0 \\
\hline Salix & 216 & 2.9 & 176 & 2.6 \\
\hline Acer & 658 & 8.8 & 187 & 2.8 \\
\hline Fraxinus & 274 & 3.7 & 522 & 7.7 \\
\hline Betula & 3057 & 40.9 & 2524 & 37.3 \\
\hline Carpinus & 110 & 1.5 & 157 & 2.3 \\
\hline Quercus & 134 & 1.8 & 220 & 3.3 \\
\hline Fagus & 7 & 0.1 & 12 & 0.2 \\
\hline Larix & 3 & 0.0 & 6 & 0.1 \\
\hline Pinaceae & 689 & 9.2 & 591 & 8.7 \\
\hline Rosaceae & 31 & 0.4 & 23 & 0.3 \\
\hline Juglans & 49 & 0.7 & 61 & 0.9 \\
\hline Aesculus & 8 & 0.1 & 27 & 0.4 \\
\hline Morus & 2 & 0.0 & 139 & 2.1 \\
\hline Sambucus & 2 & 0.0 & 0 & 0.0 \\
\hline Ligustrum & 5 & 0.1 & 3 & 0.0 \\
\hline Tilia & 11 & 0.1 & 16 & 0.2 \\
\hline $\mathbf{A P}$ & 6076 & 81.2 & 5280 & 78.1 \\
\hline Luzula & 3 & 0.0 & 3 & 0.0 \\
\hline Carex & 7 & 0.1 & 10 & 0.1 \\
\hline Poaceae & 468 & 6.3 & 564 & 8.3 \\
\hline Secale & 15 & 0.2 & 34 & 0.5 \\
\hline Rumex & 119 & 1.6 & 104 & 1.5 \\
\hline Plantago & 60 & 0.8 & 37 & 0.5 \\
\hline Urtica & 400 & 5.3 & 478 & 7.1 \\
\hline
\end{tabular}

\begin{tabular}{|c|c|c|c|c|}
\hline & \multicolumn{4}{|c|}{ Skien } \\
\hline & \multirow{2}{*}{$\begin{array}{c}1999 \\
\text { annual } \\
\text { total }\end{array}$} & \multicolumn{3}{|c|}{2000} \\
\hline & & $\begin{array}{c}\% \\
\text { share }\end{array}$ & $\begin{array}{c}\text { annual } \\
\text { total }\end{array}$ & $\begin{array}{c}\% \\
\text { share }\end{array}$ \\
\hline Corylus & 61 & 1.9 & 412 & 5.0 \\
\hline Alnus & 14 & 0.4 & 171 & 2.1 \\
\hline Taxus/Juniperus & 75 & 2.3 & 73 & 0.9 \\
\hline Populus & 7 & 0.2 & 19 & 0.2 \\
\hline Ulmus & 2 & 0.1 & 23 & 0.3 \\
\hline Salix & 10 & 0.3 & 8 & 0.1 \\
\hline Fraxinus & 17 & 0.5 & 1000 & 12.1 \\
\hline Betula & 387 & 11.8 & 1803 & 21.9 \\
\hline Carpinus & 1 & 0 & 1 & 0.0 \\
\hline Quercus & 63 & 1.9 & 187 & 2.3 \\
\hline Larix & 1 & 0.0 & 2 & 0.0 \\
\hline Pinaceae & 1142 & 34.7 & 3780 & 45.8 \\
\hline Rosaceae & 8 & 0.2 & 50 & 0.6 \\
\hline Tilia & 0 & 0.0 & 2 & 0.0 \\
\hline $\mathbf{A P}$ & 1719 & 52.2 & 7069 & 85.7 \\
\hline Luzula & 2 & 0.1 & 1 & 0.0 \\
\hline Carex & 5 & 0.2 & 2 & 0.0 \\
\hline Poaceae & 437 & 13.3 & 320 & 3.9 \\
\hline Secale & 1 & 0.0 & 3 & 0.0 \\
\hline Rumex & 24 & 0.7 & 33 & 0.4 \\
\hline Plantago & 25 & 0.8 & 16 & 0.2 \\
\hline Urtica & 881 & 26.8 & 693 & 8.4 \\
\hline Brassicaceae & 2 & 0.1 & 1 & 0.0 \\
\hline Chenopodiaceae & 5 & 0.2 & 3 & 0.0 \\
\hline Asteraceae & 1 & 0.0 & 1 & 0.0 \\
\hline Cichoriaceae & 2 & 0.1 & 1 & 0.0 \\
\hline Artemisia & 168 & 5.1 & 97 & 1.2 \\
\hline Ambrosia & 3 & 0.1 & 0 & 0 \\
\hline Apiaceae & 2 & 0.1 & 5 & 0.1 \\
\hline
\end{tabular}


Table 1 cont.

\begin{tabular}{lcccc} 
Brassicaceae & 18 & 0.2 & 8 & 0.1 \\
Chenopodiaceae & 54 & 0.7 & 44 & 0.7 \\
Asteraceae & 21 & 0.3 & 9 & 0.1 \\
Cichoriaceae & 2 & 0.0 & 0 & 0.0 \\
Artemisia & 206 & 2.8 & 137 & 2.0 \\
Iva & 14 & 0.2 & 17 & 0.3 \\
Ambrosia & 2 & 0.0 & 19 & 0.3 \\
Apiaceae & 3 & 0.0 & 3 & 0.0 \\
Humulus & 7 & 0.1 & 6 & 0.1 \\
Fabaceae & 2 & 0.0 & 0 & 0.0 \\
Lamiaceae & 2 & 0.0 & 2 & 0.0 \\
Typha & 0 & 0.0 & 3 & 0.0 \\
\hline NAP & 1403 & 18.8 & 1478 & 21.9 \\
AP+NAP & 7479 & 100 & 6758 & 100 \\
AP - Arboreal Pollen & & & & \\
NAP - Non-Arboreal Pollen & & & \\
\hline
\end{tabular}

\begin{tabular}{lcccc} 
Ericaceae & 5 & 0.2 & 2 & 0.0 \\
Lamiaceae & 10 & 0.3 & 0 & 0 \\
\hline NAP & 1574 & 47.8 & 1178 & 14.3 \\
AP+NAP & 3293 & 100 & 8247 & 100
\end{tabular}

\section{DISCUSSION}

Pollen deposition reflects the vegetation occurring in a given area. The smaller number of taxa in the pollen calendar of Skien than in Lublin is evidence of the smaller number of anemophilous plant species which grow there. The flora of Norway is poorer than in central Europe. Mountain vegetation predominantly grows there. Fixed forests with a predominance of spruce and oak (without hornbeam) reach the south-western part of the Scandinavian Peninsula. Birches - Betula pubescens, B. verrucosa - and aspen (Populus tremula) are also found there. On the other hand, Lublin lies in the climatic zone in which deciduous forests make up the main vegetation formation ( $\mathrm{Podbielkowski}$, 1995). In central Norway J o h a n s e n (1992) carried out a study on aeroplankton near a birch wood. Among 33 identified taxa, Betula, Urtica, Poaceae accounted for $75-80 \%$ of the total annual pollen count. The pollen of these taxa was also noted in large amounts in Skien. The small numbers of Pinaceae pollen grains identified by J o h a n s e n (1992) confirm the enormous influence of local plant cover on the pollen spectrum. The abovementioned author reports that the closest source of Pinaceae pollen was located at a distance of about $10-20 \mathrm{~km}$ from the sampling site.

The climate is also a very important factor affecting airborne pollen concentrations. The climatic conditions of Poland are marked by high weather variability and significant variations in seasonal weather patterns in particular years. This is associated with the transport of maritime or continental air masses ( $\mathrm{K} \mathrm{a}$ s zewski et al. 1995). The climate of Norway is mitigated under the influence of the warm Gulf Stream from the subtropical zone. In spite of the fact that Skien lies on the same latitude as Alaska, it is characterized by a much milder climate owing to the Gulf Stream. Mean annual temperature is $1.5^{\circ} \mathrm{C}$ higher in Lublin than in Skien, which promotes plant growth. Based on the present studies, large differences were found in pollen deposition at both sampling sites. In 1999 the pollen counts for most taxa were higher in Lublin than in Skien, except for Pinaceae and Urtica. But during the warmer year of 2000, higher pollen influx was noted in Skien with respect to 7 taxa. In the spring before flowering, trees and shrubs need to absorb a given amount of heat (Frenguelli et al. 1992; M in ero et al. 1999; G o n z a l e z - P a r r a d o et al. 2006). The heat requirement is generally determined genetically and varies between particular plant species (Frenguelli et al. 1991). This correlation 
was clearly visible in Skien during the study years. In Skien in 1999, mean temperature for January was $0.3^{\circ} \mathrm{C}$, for February $0.7^{\circ} \mathrm{C}$, while for March $1.6^{\circ} \mathrm{C}$, and in 2000 these values were $3.0,2.5^{\circ} \mathrm{C}$ and $3.0^{\circ} \mathrm{C}$, respectively. In Lublin in 1999, mean temperatures in January and February were relatively low, $0.1^{\circ} \mathrm{C}$ and $-1.3^{\circ} \mathrm{C}$, respectively, whereas in March a significant increase in temperature was recorded and the mean monthly temperature was $5^{\circ} \mathrm{C}$. Air temperatures in the first months of the year in Lublin and in Skien were similar in 2000. As a result of aerobiological investigations, it was found that the start of the pollen season occurred at the same time in both cities in 2000, whereas in the previous year large differences were observed (Fig. 3). In both cities, pollen grains of Corylus and Alnus first appeared in the aeroplankton. In 2000 the pollen seasons of these plants started at the same time. In Lublin there is generally a significant rise in temperature in April compared to March, whereas in Skien it takes place a month later. With increased air temperature, high pollen concentrations were observed.

According to Nils s o n and Pers s o n (1981) as well as Nils son and Palmberg-Gotthard (1982), in southern Sweden large amounts of airborne pollen are found from the end of April until the beginning of September. Similar results were obtained in Skien. Pinaceae and Betula are dominant in Skien's pollen deposition. The pollen of the abovementioned taxa is also predominant in the atmosphere of southern Sweden (Nilsson and Persson, 1981; Nilss on and Palmberg-Gotth ard,1982).

In the case of Artemisia pollen, the results of the studies conducted in Lublin and Skien were largely similar. The start dates of the pollen seasons as well as the periods of maximum pollen concentration were approximate. Similar results were obtained in other studies by various authors in Norway (Fro s t a d, 1991; R a m f j ord, 1991) and in Sweden (E k e b o m et al. 1997; Eriks s on, 1999).

R a m fjord (1991) compared the pollen counts at 10 sampling sites in Norway, situated on different latitudes. He found regional variations in pollen assemblage, primarily associated with local vegetation, meteorological conditions and the topography of the terrain. In the north in Tromsø $\left(69^{\circ}\right)$, birch sheds pollen a month later than in Oslo.

\section{CONCLUSIONS}

Due to the geographic location of Skien, it may be presumed that the pollen seasons start there later than in Lublin. The present studies show that, in favourable weather conditions, in particular with favourable temperature, the pollen season starts in Skien at the same time as in Lublin.
In Skien there was found a lower diversity of taxa in pollen deposition than in Lublin.

In both years of the study, the annual sums and maximum concentrations of Pinaceae and Urtica pollen were higher in the conditions of Norway. In the case of the other taxa, higher values were recorded in Lublin at least in one year.

Maximum pollen concentrations for most of the taxa occurred earlier in Lublin than in Skien.

\section{Acknowledgements}

I would like to express my gratitude to Urszula Andersen, the resident of Skien, for her help in sampling pollen grains for this study.

\section{REFERENCES}

D'A mato G., Spieksma F.Th.M.,1990. Allergenic pollen in Europe. Grana, 30: 67-70.

Durham O.C., 1964. Proposed standard method of gravity sampling. J. Allergy, 17: 79.

Ekebom A., Nilsson S., Saar M., van HageHamsten M., 1997. A comparative study of airborne pollen concentrations of three allergenic types. Grana, 36: 366-372.

Eriks s on N. E., 1991. Allergenic pollen and pollinosis in Sweden. In: G. D'Amato, F. Th. M. Spieksma, S. Bonini (eds), Allergenic pollen and pollinosis in Europe, Blackwell Sci. Publ., Oxford: 193-196.

Frenguelli G., Spieksma F.Th.M., Bricchi E., Romano B., Mincigrucci G., Nikkels A.H., Dankaart W., Ferranti F., 1991. The influence of air temperature on the starting dates of the pollen season of Alnus and Populus. Grana, 30: 196200.

Frenguelli G., Bricchi E., Romano B., Mincigrucci G., Ferranti F., Antognozzi E., 1992. The role of air temperature in determining dormancy release and flowering of Corylus avellana L. Aerobiologia, 8: 415-418.

Gonzalez-Parrado Z., Fuertes-Rodriguez C.R., Vega-Maray A.M., Valencia-Barrera R.M., Rodriguez-Rajo F.J., Fernandez-Gonzalez D., 2006. Chilling and heat requirements for the prediction of the beginning of the pollen season of Alnus glutinosa (L.) Gaertner in Ponferrada (León, Spain). Aerobiologia, 22: 47-53.

Frostad A.B., 1991. Allergenic pollen and pollinosis in Norway. [In:] G. D'Amato, F. Th. M. Spieksma, S. Bonini (eds), Allergenic pollen and pollinosis in Europe, Blackwell Sci. Publ. Oxford: 182-183.

J o han s en S., 1992. Aerobiological studies in subalpine birch forest at Dovrefjell, Central Norway, 1982-1984. Grana, 31: 131-142. 
Kaszewski B. M., Mrugała S., Warakomski W., 1995. Klimat. Temperatura powietrza i opady atmosferyczne na obszarze Lubelszczyzny (1951-1990). Lubelskie Towarzystwo Naukowe, Lublin.

Minero G.F.J., Morales J., Tomas C., Candau P., 1999. Relationship between air temperature and the start of pollen season emission in some arboreal taxa in Southwestern Spain. Grana, 38: 306-310.

Nilss on S, Pers on S., 1981. Tree pollen spectra in the Stockholm region (Sweden), 1973-1980. Grana, 20: 179-182.

Nilsson S., Plamberg-Gotthard J., 1982. Pollen calendar for Huddinge (Sweden), 1977-1981. Grana, 21: 183-185.

Piotrowska K., 2004. Comparison of Alnus, Corylus and Betula pollen counts in Lublin (Poland) and Skien (Norway). Ann Agric Environ Med, 11: 205-208.

Podbielkowski Z., 1995. Fitogeografia części świata. Wyd. Nauk. Państwowe Wydawnictwo Naukowe Warszawa.

R a m f jord H., 1991. Outdoor appearance of aeroallergens in Norway. Grana 30: 91-97.

Spieksma F.Th.M., 1991. Regional European pollen calendars. In: G. D’Amato, F. Th. M. Spieksma, S. Bonini (eds), Allergenic pollen and pollinosis in Europe, Blackwell Sci. Publ., Oxford: 49-65.

\section{Zróżnicowanie opadu pyłku wybranych taksonów roślin w Lublinie (Polska) i w Skien (Norwegia)}

\section{Streszczenie}

W pracy analizowano opad pyłku w Lublinie (Polska) i Skien (Norwegia). Badania prowadzono w latach 1999 i 2000 metodą grawimetryczną przy użyciu aparatu Durhama. Wyniki badań były zróżnicowane zarówno pomiędzy latami jak i miejscowościami. W Lublinie oznaczono o 10 taksonów roślin więcej niż w Skien. Największe koncentracje pyłku w powietrzu Lublina rejestrowano w kwietniu, natomiast w Skien w maju i lipcu. Na stanowisku pomiarowym w Polsce dominującymi taksonami były: Betula, Pinaceae i Poaceae a w Norwegii Pinaceae, Betula i Urtica. W ciągu dwóch lat sumy roczne pyłku większości taksonów były wyższe w warunkach Polski. Maksymalne koncentracje ziarn pyłku Betula i Poaceae były wyższe w Lublinie, zaś Pinaceae w Skien. 